\title{
Research and application progress of nanostructured bainitic steel in bearings
}

\begin{abstract}
The research and application progress of nanostructured bainitic steel in bearing manufacturing field at home and abroad are summarized in detail. Some problems on the application of nanostructured bainite on bearing that need to be solved are proposed, such as short period process, the appropriate working condition and prediction of service life. The solution of these problems will promote the application of nanostructured bainite on bearing.
\end{abstract}

Keywords: nanostructured bainite, bearing steel, wear resistance, rolling contact fatigue, progress

\author{
Volume I Issue 2 - 2017 \\ Fucheng Zhang,' Yanhui Wang, ',2 Zhinan \\ Yang, ' Yanguo Li' \\ 'State Key Laboratory of Metastable Materials Science and \\ Technology, Yanshan University, China \\ ${ }^{2}$ College of Mechanical and Equipment Engineering, Hebei \\ University of Engineering, China
}

\begin{abstract}
Correspondence: Fucheng Zhang, State Key Laboratory of Metastable Materials Science and Technology, Yanshan University, China, Tel 0086335 8063949, Fax 0086335 8074568, Email zfc@ysu.edu.cn
\end{abstract}

Received: June 05, 2017| Published: August 17, 2017

\section{Introduction}

Research into nanostructured bainitic steels has attracted much attention in the past twenty years. The nanostructured bainite was first studied by Bhadeshia and his coworkers. They reported that the nanostructured bainitic microstructure consisting of 20-40nm thick bainitic ferrite plates dispersed in retained austenite matrix exhibited a hardness value in excess of $650 \mathrm{HV} 30$, a tensile strength of $\sim 2.3 \mathrm{GPa}$ and a toughness of $30-40 \mathrm{MPa} \cdot \mathrm{m}^{1 / 2} \cdot{ }^{1-3}$ The nanostructured bainitic microstructure, which is shown in Figure 1, was formed in high-carbon $\mathrm{Si}$-rich steels by austempering at $125-350^{\circ} \mathrm{C}$ for a long time. The nanostructured bainite is also known as hard bainite owing to its high hardness, low temperature bainite because of its low transformation temperature, super bainite due to its excellent mechanical properties.

Recent years, the microstructure and mechanical properties of the nanostructured bainitic steels have been extensively studied. ${ }^{4-9}$ Meanwhile, the material researchers and the bearing production enterprises have realized the great potential of the application of nanostructured bainite in bearings and carried out the related research work gradually. This paper mainly introduces the research and application progress of the nanostructured bainitic steel in the field of bearings.

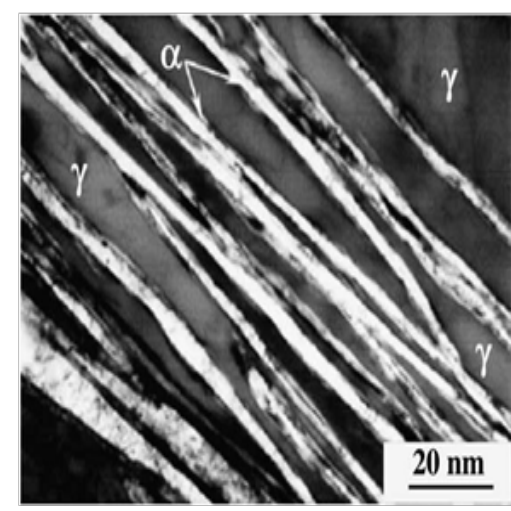

Figure I Nanostructured bainite on high carbon and high silicon steel treated at $200^{\circ} \mathrm{C}$ for 15 days. $^{3}$

\section{Nanostructured bainitic steel used for bea- rings}

A series of significant achievements have been acquired in the research and development of the nanostructured bainitic steel used for bearings in recent years. Zhang et al. have developed a variety of Al-rich nanostructured bainitic steels, whose chemical compositions are shown in Table 1, with excellent performances used for bearings and gears. ${ }^{10-17}$ The alloying element $\mathrm{Al}$ has many good effects on steel, such as promoting bainite transformation, suppressing carbide precipitation and reducing hydrogen embrittlement sensitivity. ${ }^{18}$ The nanostructured bainitic microstructure was first introduced in the surface of low-carbon steels based on carburization and succeeding low-temperature austempering at 2008, with the transformation inducing a compressive stress of about $200 \mathrm{MPa}$ into the surface,$^{10}$ which is beneficial to the rolling contact fatigue performance. The nanostructured bainitic steel achieved a service life of about two times more than the tempered martensitic steel, exhibiting an excellent resistance to rolling contact fatigue, which was shown in Figure 2. ${ }^{13}$ The excellent rolling contact fatigue resistance was mainly due to the very thin nanostructured bainitic plates ( $\sim 80 \mathrm{~nm}$ in thickness) and the fine-scale dispersion of austenite between the plates. The apparently increased hardness in the surface layer may also enhance the rolling contact fatigue resistance.

Novel high-C-Cr nanostructured bainitic bearing steels GCr15SiAl by $\mathrm{Si}-\mathrm{Al}$ alloying and GCr15SilMo by $\mathrm{Si}-\mathrm{Mo}$ alloying were developed at 2015. ${ }^{19-21}$ Research results showed that the fully nanostructured bainitic microstructure not only had excellent strength and toughness, but also had the optimal wear resistance compared with the mix microstructure of nanostructured bainite, martensite and retained austenite Table 2 and Figure 3. The microstructure without martensite but with nano-scaled bainitic ferrite ( $\sim 50 \mathrm{~nm}$ in thickness) and a small amount of film-like retained austenite was responsible for the increase in toughness, elongation and strength. The excellent wear resistance was attributed to the more thermal stability of the microstructure obtained by austempering for longer period time, which reached $72 \mathrm{~h}$. 
Supported by the national high technology research and development program of China, the novel nanostructured bainitic steels G23Cr2Ni2Si1Mo and GCr15Si1Mo used for high-power wind power bearing were developed. ${ }^{22,23}$ The carburizing G23Cr2Ni2Si1Mo bainitic steel is suitable for manufacturing high-power wind power spindle bearing ring. After carburizing plus high-temperature tempering and low-temperature austempering, nanostructured bainite with the plate thickness of $68 \mathrm{~nm}$ and dispersed carbide particles with the average equivalent diameter of $0.25 \mu \mathrm{m}$ were obtained in the surface, which were shown in Figure 4A. The rolling contact fatigue lives of the carburizing G23Cr2Ni2Si1Mo nanostructured bainitic steel were approximately $210 \%-254 \%$ greater than those of the traditional carburizing G20 Cr2Ni4 martensitic steel (Table 3 \&
Figure 5A). ${ }^{23,24}$ Moreover, the impact toughness of the center with low-carbon martensite after isothermal treatment is improved 33\% as compared with that of the oil-quenched treatment. With excellent hardenability and properties, the $\mathrm{G} 23 \mathrm{Cr} 2 \mathrm{Ni} 2 \mathrm{Si} 1 \mathrm{Mo}$ steel was chosen to manufacture $6 \mathrm{MW}$ wind power spindle bearing ring, whose external diameter reached $3200 \mathrm{~mm}$. The high- $\mathrm{C}-\mathrm{Cr}$ nanostructured bainitic bearing steel $\mathrm{GCr} 15 \mathrm{Si} 1 \mathrm{Mo}$, whose microstructure is shown in Figure 4B, has been adopted in the manufacture of rolling element of $5 \mathrm{MW}$ wind power yaw bearings, pitch bearings and spindle bearings. The rolling contact fatigue lives of the nanostructured bainitic bearing steel GCr15Si1Mo were approximately $106 \%-112 \%$ greater than those of the bainitic bearing steel GCr15SiMo (Table 3 \& Figure 5 b). ${ }^{23,25}$

Table I Chemical compositions of nanostructured bainitic bearing steel (wt\%)

\begin{tabular}{|c|c|c|c|c|c|c|c|c|}
\hline Steels & C & $\mathbf{S i}$ & Mn & $\mathrm{Cr}$ & Mo & $\mathbf{N i}$ & Al & References \\
\hline $20 \mathrm{CrMn} 2 \mathrm{MoSiNiAl}$ & 0.19 & 0.57 & I.77 & 1.37 & 0.33 & 0.42 & 1.35 & 10 \\
\hline 20CrMnMoSiAl & 0.2 & 0.36 & 1.2 & 1.35 & 0.24 & --- & 0.92 & II \\
\hline $38 \mathrm{CrMoAl}$ & 0.38 & 0.4 & --- & 1.37 & 0.23 & --- & 1.03 & 14 \\
\hline G23Cr2Ni2Si IMo & $0.20 \sim 0.25$ & $1.20 \sim 1.50$ & $0.20 \sim 0.40$ & $1.35 \sim 1.75$ & $0.25 \sim 0.35$ & --- & $\leq 0.05$ & 22 \\
\hline G23Cr2Ni2SiMoAl & $0.20 \sim 0.25$ & $0.90 \sim 1.20$ & $0.20 \sim 0.40$ & I.35 1.75 & $0.25 \sim 0.35$ & --- & $0.30 \sim 0.50$ & \\
\hline GCrI5SiAl & 1.15 & 0.58 & 0.21 & $\mathrm{I} .42$ & --- & --- & 0.65 & 19 \\
\hline GCrI5SilMo & $0.95 \sim 1.05$ & $1.20 \sim 1.50$ & $0.20 \sim 0.40$ & I. $40 \sim 1.70$ & $0.30 \sim 0.40$ & --- & $\leq 0.05$ & 20,23 \\
\hline
\end{tabular}

Table 2 Properties and phase constitutions of GCrI5SiAl steel after austempered for different time. ${ }^{19}$

Note: $f_{V A}, f_{V B}, f_{V M}, f_{V C}$ stands for the volume fraction of retained austenite, bainite ferrite, martensite and undissolved carbides respectively.

\begin{tabular}{|c|c|c|c|c|c|c|c|c|c|}
\hline Holding time $(\mathrm{H})$ & AK (J) & Hardness & UTS & YS & El & $\mathbf{F}_{\mathrm{VA}}$ & $\mathbf{F}_{\mathrm{VB}}$ & $\mathbf{F}_{\mathrm{vM}}$ & $\mathbf{F}_{\mathrm{vc}}$ \\
\hline & & (HRC) & (MPa) & (MPa) & (\%) & (\%) & (\%) & (\%) & (\%) \\
\hline 2 & 12 & 62 & 2277 & 2158 & 1.5 & 22.3 & 2.1 & 69.6 & 6 \\
\hline 6 & 30 & 58 & 1614 & 890 & 2 & 45.3 & 40.8 & 7.4 & 6.5 \\
\hline 12 & 52 & 61 & 1826 & 1180 & 2.6 & 29.5 & 60.2 & 3.5 & 6.8 \\
\hline 72 & 66 & 61.3 & 2373 & 1697 & 3.5 & 7.2 & 86.6 & 0 & 6.2 \\
\hline
\end{tabular}

Table 3 Comparison on the rolling contact fatigue lives of the new developed and the traditional bearing steels

Note: $\beta$-Weibull slope, $\mathrm{L}_{10}$-rated life, $\mathrm{L}_{50}$-median life, $\mathrm{V}_{\mathrm{s}}$-characteristic life.

\begin{tabular}{lllll}
\hline Steels & $\beta$ & $\mathbf{L}_{10} /\left(\times 10^{7}\right)$ & $\mathbf{L}_{50} /\left(\times 10^{7}\right)$ & $\mathbf{V}_{\mathrm{s}} /\left(\times 10^{7}\right)$ \\
\hline G23Cr2Ni2SiIMoA & 1.582 & 1.375 & 4.534 & $5.7 \mid 4$ \\
G20Cr2Ni4A ${ }^{24}$ & 1.742 & 0.444 & 1.308 & 1.614 \\
Life increase of new steel & -- & $210 \%$ & $246 \%$ & $254 \%$ \\
GCrI5SilMo & 2.117 & 1.326 & 3.228 & 3.838 \\
GCrI5SiMo 25 & 2.02 & 0.645 & 1.484 & 1.812 \\
Life increase of new steel & -- & $106 \%$ & $117 \%$ & $112 \%$ \\
\hline
\end{tabular}



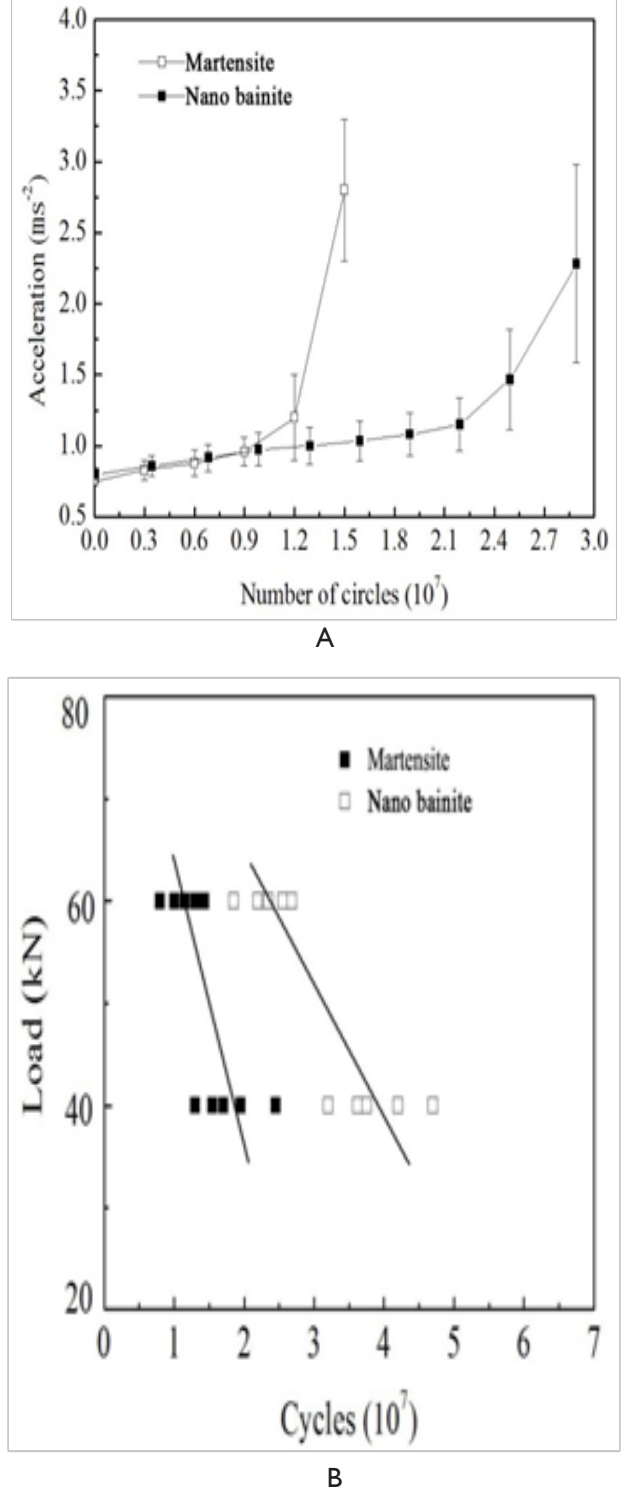

Figure 2 Rolling contact fatigue performances of nanostructured bainitic steel $20 \mathrm{CrMnMoSiAl}$ and martensitic steel $20 \mathrm{CrMnTi}:^{13}$ (a) the vibration curves, (b) the lives under different loads (The straight lines in Fig $2 \mathrm{~b}$ represent the average values of the rolling contact fatigue life).

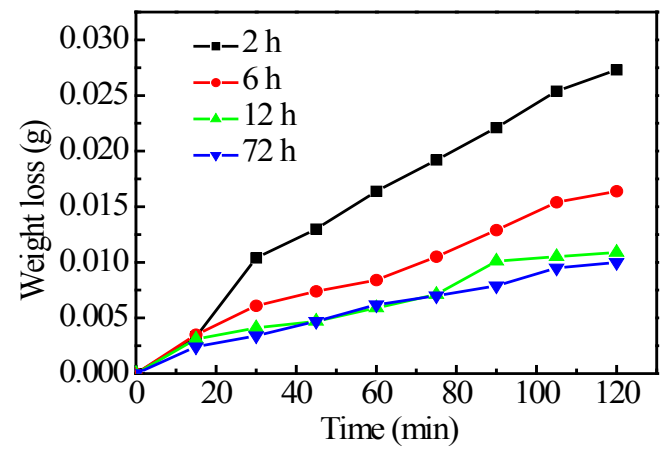

Figure 3 Comparison on the wear resistant of GCrI5SiAl steel with different phase constitutions. ${ }^{19}$
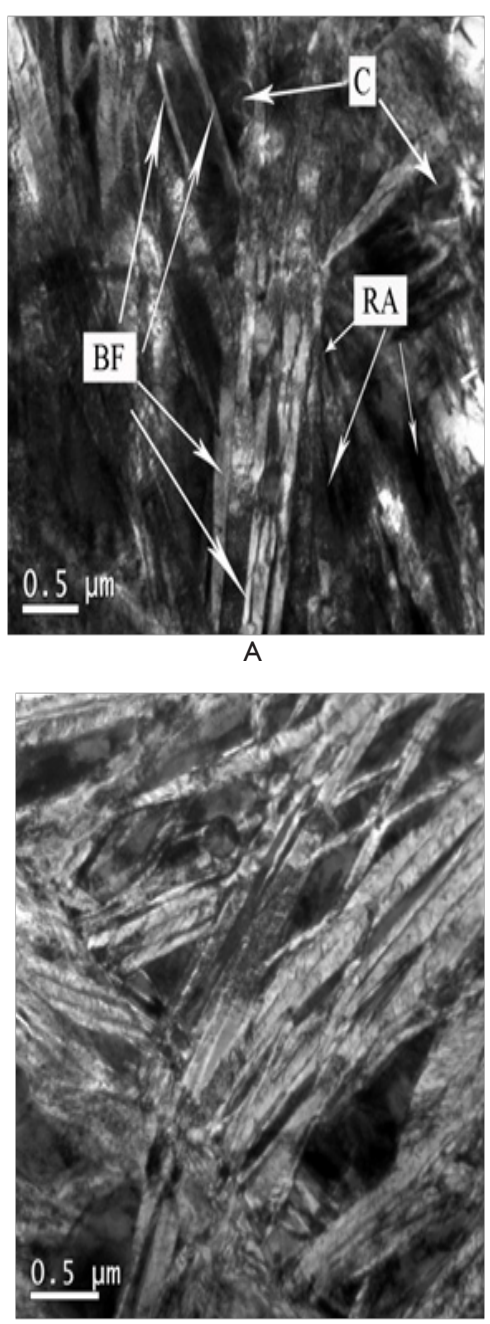

B

Figure 4 TEM micrographs of nanostructured bainitic microstructure in the surface layer of G23Cr2Ni2Sil Mo steel (a) and GCrI5Sil Mo steel (b).

Solano-Alvarez et al. ${ }^{26}$ have studied the rolling contact fatigue phenomena and proposed the damage mechanism of a nanostructured bainitic steel without undissolved carbides intended for bearing applications. They pointed out that the degradation mechanism is ductile void formation at the interfaces, followed by growth and coalescence into larger voids that cause fracture along the direction of the softer phase. This degradation mechanism is different from the conventional damage mechanism, which involves crack initiation at inclusions and propagation in typical bearings steels. Liu et al. ${ }^{27}$ have reported that the rolling contact fatigue life of an ultrahigh carbon steel with a mixed microstructure composed of nanostructured bainite, martensite, retained austenite, and un-dissolved carbides is approximately 3.3 times longer than that of the steel with tempered martensite. The improvement in the rolling contact fatigue life of the steel is attributed to nanostructured bainite and stable filmlike retained austenite. The nanostructured bainite can delay crack initiation via alleviating the stress concentration at the hard phases (such as carbide particles or non-metal inclusions), and the stable film-like retained austenite can retard crack propagation. These research findings provide a theoretical basis and technical support for the eventual usage of nanostructured bainitic steels in rolling bearing field. 
The dimensional stability is crucial to bearings, especially for the precision bearings. Studies have shown that the nanostructured carbide-free bainite experienced nearly no distortion. ${ }^{28}$ The dimension change of $100 \mathrm{Cr} 6$ bearing steel after bainitic austempering was five times larger than that of the nanostructured bainitic steel. Wang et al. ${ }^{29,30}$ have reported that the sliding wear resistance and the highcycle bending fatigue performance of the nanostructured bainite were superior to those of the tempered martensite with the same chemical composition. Besides, the wear resistance in dry rolling-sliding of the nanostructured bainitic steels was also significantly superior to that of the bainitic steels transformed at higher temperatures with similar hardness values. ${ }^{31}$ In order to develop nanostructured bainitic steels intended for bearing applications, Swedish SKF Company has established University Technology Center together with University of Cambridge. ${ }^{32}$
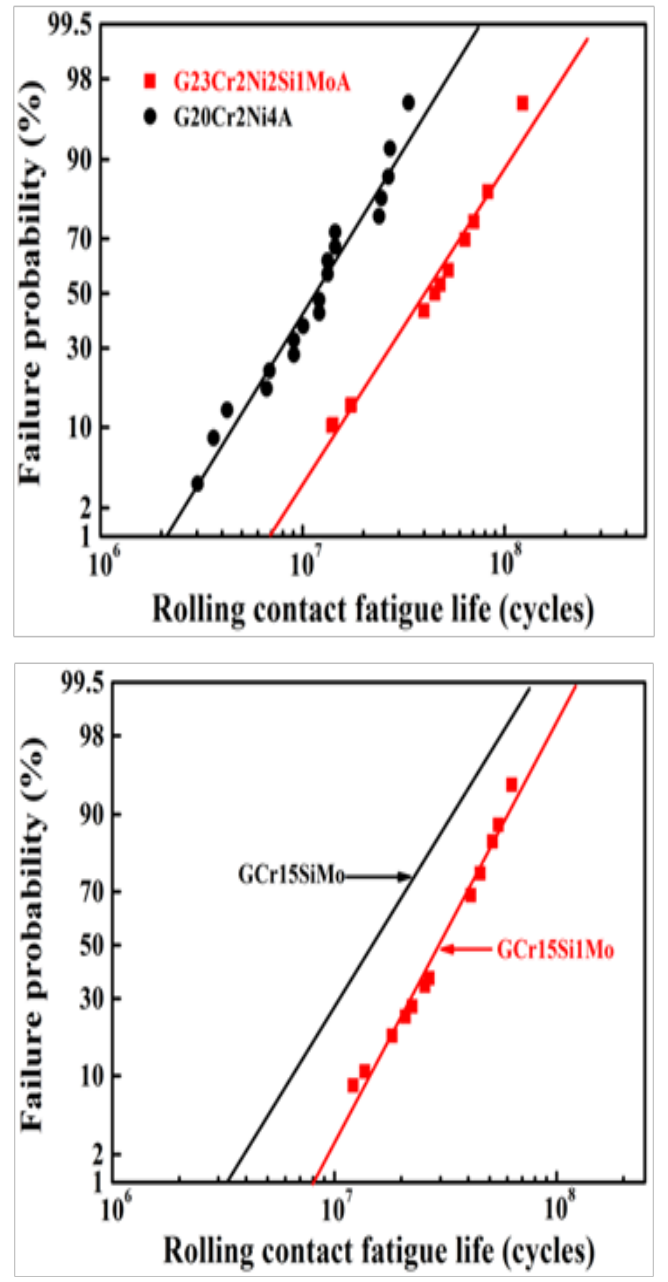

Figure $5 \mathrm{P}-\mathrm{N}$ curves of rolling contact fatigue of new developed bearing steels.

\section{Outlook}

The nanostructured bainitic microstructure, which is consisting of nano-scale extremely fine bainitic ferrite plates and carbon-enriched retained austenite film, possesses high strength, high toughness, excellent wear resistance and rolling contact fatigue performance and has a good application prospect in the bearing steel. However, the application of nanostructured bainitic bearing steel is still in its infancy at present. Therefore, there are still some problems needed to be further in-depth studied, for example, the transformation of retained austenite during the serving process and the dimensional stability problem caused by it, the microstructure evolution during bearing service and its influence on service life, what kind of working condition is more suitable for the nanostructured bainitic bearing steel, shortening the cycle of the heat treatment process and so on. Hoping that there are more bearing industries and related scientific or technical workers to research and solve these problems together, promoting the development and application of the nanostructured bainitic bearing steels.

\section{Acknowledgements}

This work was supported by the National High Technology Research and Development Program of China (863 Program) (Grant No. 2012AA03A504) and the Natural Science Foundation of China (No. 51471146)

\section{Conflict of interest}

The author declares no conflict of interest.

\section{References}

1. Caballero FG, Bhadeshia HKDH, Mawella KJA, et al. Very strong low temperature bainite. Materials Science and Technology. 2002;18(3):279284

2. Garcia-Mateo C, Caballero FG, Bhadeshia HKDH. Development of hard bainite. ISIJ International. 2003;43(8):1238-1243.

3. Caballero FG, Bhadeshia HKDH. Very strong bainite. Current Opinion in Solid State and Materials Science. 2004;8(3-4):251-257.

4. Bhadeshia HKDH. Nanostructured bainite. Proceedings of the Royal Society A. 2010;466(2113):3-18

5. Bhadeshia HKDH. Steels for bearings. Progress in Materials Science. 2012;57(2):268-435.

6. Tsai YT, Lin CR, Lee WS, et al. Mechanical behavior and microstructural evolution of nanostructured bainite under high-strain rate deformation by Hopkinson bar. Scripta Materialia. 2016;115:46-51

7. Luo P, Gao GH, Zhang H, et al. On structure-property relationship in nanostructured bainitic steel subjected to the quenching and partitioning process. Materials Science and Engineering: A. 2016;661:1-8.

8. Sourmail T, Garcia-Mateo C, Caballero FG, et al. Tensile ductility of nanostructured bainitic steels: influence of retained austenite stability. Metals. 2017;7(1):31.

9. Peet MJ, Fielding LCD, Hamedany AA, et al. Strength and toughness of clean nanostructured bainite. Materials Science and Technology. 2017;33(10):1171-1179

10. Zhang FC, Wang TS, Zhang P, et al. A novel method for the development of a low-temperature bainitic microstructure in the surface layer of lowcarbon steel. Scripta Materialia. 2008;59(3):294-296.

11. Zhang P, Zhang FC, Wang TS. Preparation and microstructure characteristics of low-temperature bainite in surface layer of low carbon gear steel. Applied Surface Science. 2011;257(17):7609-7614.

12. Zhang P, Zhang FC, Yan ZG, et al. Wear property of low-temperature bainite in the surface layer of a carburized low carbon steel. Wear. 2011;271(5-6):697-704.

13. Zhang P, Zhang FC, Yan ZG, et al. Rolling contact fatigue property of low-temperature bainite in surface layer of a low carbon steel. Materials Science Forum. 2011;677:585-588. 
14. Zhang $\mathrm{P}$, Zhang FC, Yan ZG, et al. $\mathrm{N}$ rich nanocrystalline bainite in surface layer of carbon steel. Surface Engineering. 2013;29(5):331-335.

15. Zhao J, Hou CS, Zhao G, et al. Microstructures and mechanical properties of bearing steels modified for preparing nanostructured bainite. Journal of Materials Engineering and Performance. 2016;25(10):4249-4255.

16. Su LT, Zhang FC, Zheng CL, et al. Effect of heat treatment process and hydrogen charging on compression properties of GCr15SiMoAl bearing steel. Transactions of Materials and Heat Treatment. 2017;38(2):111117.

17. Zhang FC, Yang ZN, Lei JZ, et al. Application progress of bainite stee in bearings. Bearing. 2017;1:54-64.

18. Li YG, Chen $\mathrm{C}$, Zhang $\mathrm{FC}$. $\mathrm{Al}$ and $\mathrm{Si}$ influences on hydrogen embrittlement of carbide-free bainitic steel. Advances in Materials Science and Engineering. 2013;2013(11):1-7.

19. Zhao J, Wang TS, Lv B, et al. Microstructures and mechanical properties of a modified high-C-Cr bearing steel with nano-scaled bainite. Materials Science and Engineering: A. 2015;628:327-331.

20. Zhao J, Zhao T, Hou CS, et al. Improving impact toughness of high-C$\mathrm{Cr}$ bearing steel by $\mathrm{Si}-\mathrm{Mo}$ alloying and low-temperature austempering. Materials \& Design. 2015;86:215-220.

21. Shan J, Zheng CL, Zhang FC, et al. Study on spheroidizing annealing of GCr15SiAlMo bainitic bearing steels. Journal of Mechanical Engineering. 2015;51(4):47-57.

22. Wang YH, Yang ZN, Zhang FC, et al. Microstructures and mechanical properties of surface and center of carburizing 23Cr2Ni2Si1Mo steel subjected to low-temperature austempering. Materials Science and Engineering: A. 2016;670:166-177.

23. Wang YH, Zhang FC, Yang ZN, et al. Rolling contact fatigue performances of carburized and high-C nanostructured bainitic steels. Materials. 2016;9(12):960.
24. Wu XM, Yang YM, Dong YX, et al. Experimental research on the contact fatigue life of GCr4, G20CrNi2Mo and G20Cr2Ni4 steels. Bearing. 2001;7:29-30.

25. Yan GC, Ye JY. Structure and Properties of Steel GCr15SiMo Austempered. Bearing. 2006;9:21-22.

26. Solano-Alvarez W, Pickering EJ, Bhadeshia HKDH. Degradation of nanostructured bainitic steel under rolling contact fatigue. Materials Science and Engineering: A. 2014;617:156-164.

27. Liu HJ, Sun JJ, Jiang T, et al. Improved rolling contact fatigue life for an ultrahigh-carbon steel with nanobainitic microstructure. Scripta Materialia. 2014;90-91(6):17-20.

28. Amey CM, Huang H, Rivera-Díaz-del-Castillo PEJ. Distortion in 100Cr6 and nanostructured bainite. Materials \& Design. 2012;35:6671.

29. Yang J, Wang TS, Zhang B, et al. Sliding wear resistance and worn surface microstructure of nanostructured bainitic steel. Wear. 2012;282283(1):81-84

30. Yang J, Wang TS, Zhang B, et al. High-cycle bending fatigue behaviour of nanostructured bainitic steel. Scripta Materialia. 2012;66(6):363366

31. Leiro A, Vuorinen E, Sundin KG, et al. Wear of nano-structured carbide-free bainitic steels under dry rolling-sliding conditions. Wear. 2013;298-299(1):42-47.

32. http://www.msm.cam.ac.uk/skf/index.html 